\title{
3 \\ The Question of Quality
}

The quality of higher education throughout the Middle East and North Africa is characterized by the rhetoric of an all-consuming crisis (Boutieri, 2016; Waterbury, 2020). Technical experts, academics, and policymakers largely agree that higher education, like the primary and secondary schooling before it, suffers from low quality (Badran, Baydoun, \& Hillman, 2019). This low quality is blamed for the region's high unemployment rates and weak economic growth (World Bank, 2008b). Concerns over low quality take on heightened significance when framed in terms of the knowledge economy, in which quality is linked to economic growth and development. In response, Arab governments have enacted ambitious reform initiatives to improve quality.

This chapter deconstructs the narrative of low quality that dominates current thinking about higher education development in the region and examines countries' approaches to improving quality. It argues that large-scale quality-assurance reforms are state projects aimed at securing legitimacy from sceptical publics at home and abroad. At the same time, because it can be delegitimizing for Arab states to acknowledge that their public higher education systems are failing, large-scale quality-assurance reforms demand significant political will. For lowand middle-income countries in the region, quality assurance is tied to major government-led reforms and supported financially by the WB, which has the dual benefit of securing finances and signalling state investment in quality. In North Africa, ministries have restructured degrees to mirror those in Europe. Meanwhile, in wealthy Arab Gulf states, quality assurance is not resource generating; rather, foreign consultants and think-tanks seek to align Gulf systems to best practices in the United States and the United Kingdom. Despite their differences throughout the region, the approaches to quality all look to external, foreign, or international models as blueprints for success. This implicit 
encoding of high quality as "foreign" often sidesteps national policy processes, disregards local perspectives on quality, and ignores the interests of affected stakeholders.

Moreover, despite their efforts, quality-assurance reforms seem to have had a limited impact on teaching and learning in classrooms and in many cases have become subject to politicization. I argue that technical reforms that seek to assure a high quality miss two fundamental points, one socio-political and one educational. First, overly technical approaches ignore the social and political purposes of higher education as a marker of status and a positional good. As the primary statelegitimized product of a university, the degree promises employment and social status. As a result, even seemingly technical issues, such as how to define and measure quality, are embedded within a broader web of a socio-political power over the meaning and power of a university credential and over who should have access to that power.

Second, the technical approach to quality, which implies that the degree of quality can be distilled into measurable and quantifiable indicators, overlooks the fact that teaching and learning are relational: students learn in relation to one another, their professors, the ideas of those who have come before, and also to their selves, past and future. Numeric indicators, including class size and library volumes, are hardly a proxy for the quality of these relationships. My own teaching and fieldwork in the region have continuously impressed upon me the reality that professors in the region are as intelligent, creative, and hard working as professors anywhere in the world. In their nations they are teaching the best and brightest students: hard-working, creative young people who are striving to build better futures for themselves, their families, and their societies amidst major constraints. Perhaps a new approach to improving quality would start with centring the relational aspect of teaching and learning and looking for forms of "everyday excellence" that already exist throughout the region, despite being undermined by the pervasive crisis rhetoric.

\section{The Global Race for High Quality}

The so-called quality crisis in Arab higher education must be understood within a global emphasis on educational quality that positions higher education as crucial to economic competitiveness in a global knowledge economy. In the era of globalization, nation states are portrayed as competing with one another for scarce resources, including human resources in the form of skilled labour or "talent" (Brown \& Tannock, 2009). Scholars have called this discursive shift, emblematic 
of neoliberalism, as a shift from the "welfare state" to the "competition state" (Levi-Faur, 2005). The need to improve quality has been mapped onto diverse policy agendas and used to initiate large-scale reforms to educational systems, including curricular reform, program structure, and pedagogical practices.

In 1998, UNESCO convened over 180 countries for the first global conference on higher education, called the World Conference on Higher Education in the Twenty-First Century. Supporting high-quality higher education signals a desire and a willingness to participate in the knowledge economy and to ensure that countries are competitive economically in this new global era (Stromquist, 2002). These commitments made at the world conference were reaffirmed at an annual meeting of the Arab League Educational, Cultural and Scientific Organization in 2001, where governments committed to supporting quality assurance through the creation of new regulatory offices (Arafeh, 2010).

Despite the consensus on the need for high quality, definitions of quality are surprisingly rare. UNESCO has defined quality as a "multidimensional concept" that must encompass "all functions and activities" of higher education including "teaching and academic programmes, research and scholarship, staffing, students, buildings, facilities, equipment, services to the community and the academic environment" (UNESCO, 1998, p. 26). What this comprehensive definition means in practice for the university, professors, or students is unclear. Moreover, while an underlying assumption is that quality refers to the quality of student learning, in much of the development literature it tends to be measured in ways that are far removed from students' lives, including numerical indicators of student-faculty ratios, faculty publications, and employment outcomes. Yet, it is these same indicators that are used to decry the state of quality in Arab higher education.

\section{The Crisis}

For the past three decades the quality of higher education in the Middle East and North Africa region has been decried in local media and international reports. A 2011 report by the Brookings Institution titled Higher Education in the Arab World states: "Despite more than a decade of dramatic expansion - in enrolment, female participation, numbers of institutions, and programs - higher education in the Arab world continues to fall far short of the needs of students, employers, and society at large" (Wilkens \& Masri, 2011, p. iii). The assumption of failure is pervasive. In their foreword to one of the most comprehensive books on young people's lives in the region, Generation in 
Waiting, Dr. Anwar Mohammed Gargash, the minister of foreign affairs for the United Arab Emirates, and James Wolfensohn, a former WB president, write that "the quality of education in the region is often low, leaving young people unprepared to compete in the global economy" (Dhillon \& Yousef, 2011, p. ix).

This rhetoric is not new. Since the 1980s, Arab academics and officials have worried about declining quality, particularly in the region's middleincome countries, largely due to overcrowding of public universities (Kohstall, 2012). In 2002 the United Nations Development Programme (UNDP) wrote its first regional report on the state of human development in the Arab states, Arab Human Development Report: Creating Opportunities for Future Generations. While lauding the substantial expansion in access at all levels of education, the report declared that poor quality was "the Achilles heel of education in the Arab world, a flaw that undermines its quantitative achievements" (UNDP, 2002, p. 54). The report makes a clear link between the low quality of education and the high rates of unemployment in Arab societies: "Problems of quality and relevance have led to a significant mismatch between the labor market and development needs on the one hand and the output of education systems on the other ... The prevalence of unemployment among the educated and the deterioration in real wages for the majority of them exemplify this problem" (p. 54). The report states that there is a "crisis in human development in the Arab region," and in particular there is a "crisis in education" (p. 54), later referred to as "the education crisis" (p. 56). In the 180-page report, the word crisis is used five times - three times in the three pages dedicated to education, compared to only once with reference to technology and once with reference to political systems.

Since the release of the first Arab Human Development Report in 2002, five additional $A H D R s$ have been published, each focusing on a key issue affecting human development: knowledge (2003), freedom (2004), women and gender (2005), security (2009), and, most recently, youth (2016) (UNDP, 2003, 2004, 2005, 2009, 2016). The reports, which have become highly influential and characterize what Sukarieh (2017) calls a "regime" that constitutes a legitimized source of knowledge about the region, have shaped approaches to development among Western donors and governments (p. 72). Over the past two decades the AHDRs have consistently emphasized the idea that the region suffers from low-quality higher education (Bayat, 2005). For example, the 2005 Arab Human Development Report cites the "lack of knowledge capital as the main long-term problem faced by the Arab world and calls declining quality the most important challenge faced by Arab education" (Gonzalez, Karoly, Constant, Salem, \& Goldman, 2008, p. 2). 
More recently, the 2016 AHDR focuses specifically on the challenges that young people face. Yet, there is surprisingly little new analysis of higher education. In the introductory material the first mention of the word education narrowly frames the purpose of education within the context of work, stating that many Arab youth "continue to receive an education which does not reflect the needs of labour markets" (UNDP 2016, p. 5). Similarly, the report's chapter on education, titled "Education and the Transition to Work," implicitly defines the social role of education as its link to employment. Despite bringing new attention to inequalities, the majority of the chapter is actually focused on employment, including job creation, school-to-work transitions, and labour market policies. The authors state that "quality" can be conceptualized as "educational achievement" and be measured by scores on standardized international assessments. Yet the chapter does not discuss what quality looks like in higher education, where there are no standardized international assessments. Instead, it repeats an oft-stated, rarely supported claim that "Arab countries suffer from under-enrolment in scientific disciplines among secondary and tertiary students and a continued reliance on outdated pedagogical techniques such as rote memorization" (p. 74).

The UNDP is not alone in making critiques of quality. In 2013 a report on Arab knowledge economies, published by the Center for Mediterranean Integration at the $\mathrm{WB}$, reiterated the same idea, stating that "the relationship between education and economic growth has remained weak, the divide between education and employment has not been bridged, and the quality of education continues to be disappointing" (CMI, 2013, p. 47). In an interview on how the Arab world should respond to the Arab Spring, WB senior education specialist Adriana Jaramillo stated that universities in the region must "equip young people with the sort of skills relevant to today's labor markets" (World Bank, 2011). In short, there is a clear consensus in the development literature that higher education suffers from low quality and is largely responsible for poor labour market outcomes in the region.

Many scholars have critiqued the premises and arguments made in the various iterations of the Arab Human Development Report and related publications that frame youth integration as a social problem (Abu-Lughod, 2009; Adely, 2009; Hasso, 2009; Jad, 2009; Mazawi, 2009; Sukarieh, 2017). Major critiques state that the AHDRs essentialize Arab culture as static and inherently patriarchal (Abu-Lughod, 2009; Lavergne, 2004) and that women are portrayed as passive and oppressed (Abu-Lughod, 2009; Adely, 2009; Adely, Haddad, et al, 2019). Hasso (2009) deconstructs how the 2005 AHDR operates within a 
state-led development paradigm (advocated by the UNDP) that seeks to strengthen governments and elites at the expense of broader constituencies, including the marginalized and activists. These scholars' close readings of the AHDRs are important contributions to debates on the ways in which powerful agencies advance particular narratives about human development, and they remind us not to accept sweeping generalization uncritically. In the next section I build on the tradition of close reading to unpack the varied lines of argument that frame the discussion of the "quality crisis" in the development literature.

\section{The Technical Approach to Quality}

The widespread consensus that higher education in the Arab world suffers from low quality brings together a number of lines of argument that link low student learning to dire economic conditions. It contends first that the offerings and outputs of the higher education system are poor, and second, that due in part to the low-quality output, there is a mismatch between the needs of the labour market and the skills of graduates (Adely, Mitra, Mohamed, \& Shaham, 2021; Assaad, Krafft, \& SalehiIsfahani, 2018). Third, it suggests that this mismatch is to be blamed for sluggish economic growth and high rates of unemployment in the region.

On the first point, the technical literature suggests that students are not actually learning very much in university due to poor-quality inputs and a lack of incentives for learning. Commonly criticized are the large class sizes, deteriorating facilities, and overly theoretical or outdated programs of study. Faculties are also roundly criticized for having outdated teaching methods that rely on rote memorization and that do not require students to be creative producers of knowledge or analytical thinkers.

These critiques of large class sizes and deteriorating facilities are not unfounded. Throughout North Africa, universities are like mid-sized cities, with campuses that were built in the middle of the twentieth century for fewer and more elite students. Public universities in Fez and Marrakech enrol upwards of 60,000 students, and Cairo University has over 100,000 students. It is not uncommon to hear stories of students attending lectures with standing room only and an inability to hear professors from the back of the room. This large number of students inflates student-teacher ratios. For example, in interviews that I conducted with faculty members in 2013, I was told that in an English department with 5,000 students in Fez there were only 26 full-time professors, which translates into a student-faculty ratio of 192 students per faculty member. 
This does not mean, however, that such large classes are necessarily the norm. In the semester during which I taught at Mohammed V University in Morocco, my two classes held from thirty to forty students, roughly the same number that I taught in a master's program at Columbia University. In the dozens of classes that I observed at universities in the UAE, Lebanon, Morocco, and Jordan, they had roughly twenty to thirty students. Meanwhile, we know that class sizes in introductory classes around the world, including in the United States and Canada, can reach one thousand. Small class sizes alone cannot be equated with a high level of quality, particularly in higher education, where much of the onus for learning is placed on students' independent study. In fact, in the field of higher education, scholars recognize that while neither faculty members nor students enjoy large classes, there are diverse ways of learning, and student learning depends significantly on subject matter and pedagogical style - meaning that large class sizes alone must not be equated with a lack of learning.

Moreover, claims of low quality are rarely substantiated with either evidence or nuance. Figure 3.1 shows the average number of students per faculty member in each world region, using data from the World Development Indicators. To calculate the regional averages, I took the average of country ratios, using the latest year of data available for each country. The ratio in the Middle East and North Africa, with a regional average of 20.9, is higher than in many regions, but not out of line with the global average, and substantially below averages found in subSaharan Africa and Southeast Asia.

Blame for low levels of learning is also placed on students' choice of concentrations or fields of study. The major critique is that their concentrations are in the humanities and social sciences, rather than in the scientific and technical fields that are considered imperative for knowledge economies. In its 2008 report the WB explained that one of its measures of quality was the proportion of all university students majoring in science, technology, engineering, and mathematics (STEM); its underlying assumption was that "scientists and engineers are likely to contribute more to economic growth than are social scientists and students of humanity because of the increasing importance of technological innovation and adaptation in the development process" (World Bank, 2008b, p. 20). To support this claim, the authors cite one study from 1991 - seventeen years before their study was published and well before the global spread of the personal computer, internet, and mobile technology. The assumption that the sciences as a concentration are a measure of quality is nonetheless widely accepted in the region. In a study of higher education finance in Jordan, Taher Kanaan, a former 
Figure 3.1. Average Student-Teacher Ratio in Tertiary Education, by Region

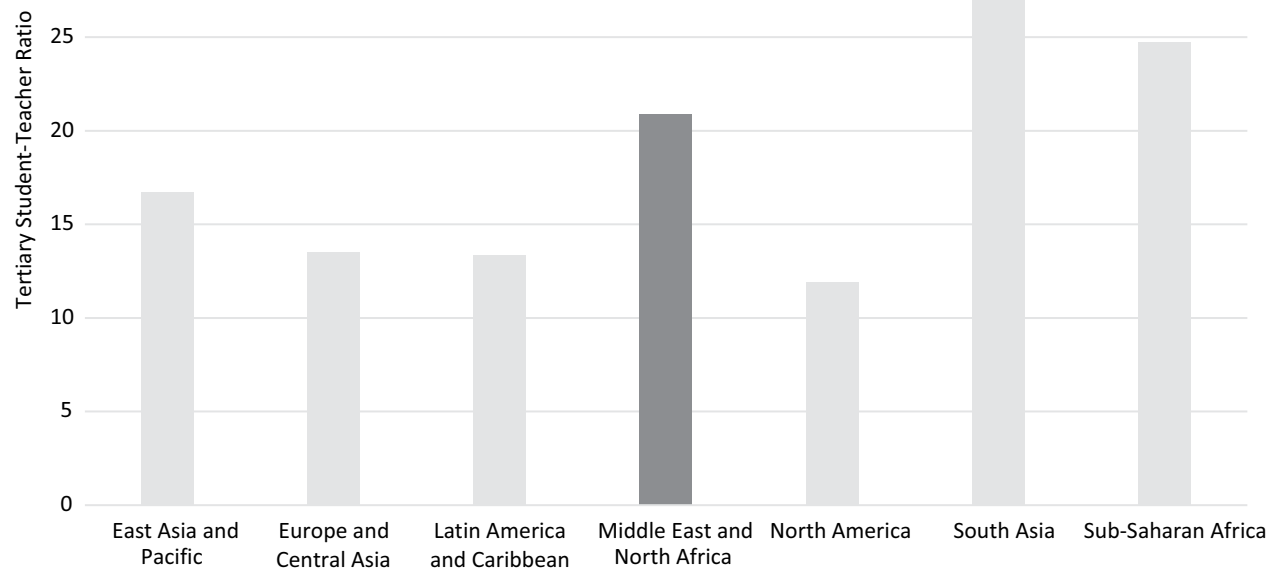

Note: Data accessed through the WB Open Data module for Stata. Indicator SE.TER. ENRL.TC.ZS (Azevedo, 2011).

minister of higher education in that country, stated: "The proportion of university students enrolled in science and engineering compared to humanities and social sciences could be viewed as an index of the quality of human capital at the higher education level" (Kanaan, Salamat, \& Hanania, 2011, p. 40).

In fact, the claim that too many students in the Middle East and North Africa are majoring in the social sciences and too few are majoring in science, engineering, and other technical fields is belied by cross-national evidence. Figure 3.2 shows the regional mean of the percentage of students majoring in either STEM fields or in the social sciences, arts, and humanities, using data from the World Development Indicators on graduates' concentrations. The WDI include data on the percentage of all tertiary students graduating from various programs, such as the social sciences, natural sciences, and arts and humanities, as well as engineering, education, and agriculture. To create this figure, I grouped arts and humanities graduates with social sciences, journalism, and information into one category and grouped graduates in 
Figure 3.2. Higher Education Graduates as a Percentage of the Total, by Field and Region

40

35

30

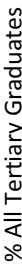

25

$\frac{7}{0}$

$\frac{1}{\pi} 20$

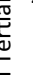

15

10

5

0

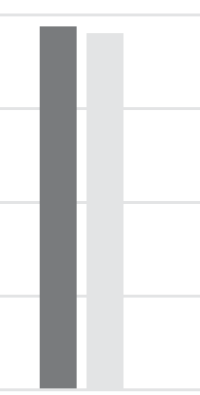

East Asia and Pacific

Europe and

tin America Central Asia and Caribbean

Middle East North America and North

Africa

n STEM Programs

Social Sciences, Arts and Humanities Programs

Source: Data accessed through the WB Open Data module for Stata. Indicators SE.TER.GRAD.SS.ZS; E.TER.GRAD.SC.ZS; SE.TER.GRAD.EN.ZS; SE.TER.GRAD. HU.ZS (Azevedo, 2011)

natural sciences, mathematics, and statistics with those in engineering, manufacturing, and construction to create a STEM category. These two indicators do not equal 100 per cent because they do not account for all tertiary programs, such as education. To calculate the regional averages, I took an unweighted average of all the country percentages in the region, using the latest year of data available.

The figure shows that countries in the Middle East and North Africa have the highest proportions of students graduating with STEM degrees of any world region, at 23.5 per cent, and which closely mirrors the percentage in North America (21.6).

Moreover, there is very little research to support the idea that Arab economies would benefit from having more STEM graduates. Recent 
economic research has argued that social sciences and humanities education may be one of the factors driving the growth of creative economies and entrepreneurialism in the United States and other advanced economies (Hanushek \& Woessmann, 2015). The link between education and economic growth is not a simple equation - more STEM graduates certainly do not equate to more employed youth or more rapidly growing economies. And yet, much of the technical literature on higher education in the region makes blanket statements about the region's need for more STEM graduates, with very little empirical support.

Many of the greatest criticisms are directed at professors' pedagogy. The didactic pedagogies common throughout the region are decried as out of date and ill-preparing students for the labour market, which demands students to be analytical, critical thinkers. Waterbury (2020) phrases this as "a massive pedagogical failure" (p. 4) and cites a former Jordanian minister of education as singling out "the prevalence of rote learning and the uncritical acceptance of text, which yield obedience to power as well as intolerance" (p. 4). What is striking, however, is that the claims about outdated teaching methods are rarely supported by empirical evidence. In fact, in my many years of observing professors in higher education in the Arab world, I have seen a broad range of teaching styles, from small and intimate seminar discussions to instruction in large lecture halls. What I have not seen is evidence that teaching and learning in Arab classrooms is fundamentally different or worse than that in classrooms around the world, aside from their generally fewer resources. Moreover, it is worth remembering that concerns over faculty pedagogy are common around the world, and academic powerhouses, including China and France, have long relied on rote memorization in universities, without being subject to similar narratives of crisis.

Assessments of the outputs of the education system fare even worse. Outputs are typically measured through performance on international exams at the lower levels of education, and through the global rankings of universities at the level of higher education. A 2009 article by the Economist is indicative of the general thinking that Arab universities are falling behind those of other regions, stating: "A listing of the world's top 500 universities, compiled annually by Shanghai Jiao Tong University, includes three South African and six Israeli universities, but not a single Arab one" ("Laggards," 2009). A 2016 Brookings blog post echoes this sentiment, stating: "Only two or three Arab universities are in the list of the top 500 universities in the world (and none are in the top 200)" (Devarajan, 2016). It is worth pointing out that several universities in the Arab world - including King Saud University (Saudi Arabia), King Fahd University of Petroleum and Minerals and Cairo University 
(Egypt), and the American University of Beirut (Lebanon) - now rank in the top five hundred. These international rankings are widely criticized in the academic literature on higher education because of their arbitrary indicators such as the number of Nobel Prize winners or the percentage of international students; yet, they often pass as strong evidence in development reports (Marginson \& Van der Wende, 2007).

The region's poor quality of higher education is subsequently linked to the high rates of unemployment, which is portrayed as the real crisis because young unemployed youth, particularly men, are viewed as a security threat to many states. The 2002 AHDR refers to unemployment as the "scourge of joblessness, which afflicts Arab countries as a group more seriously than any other developing region" (p. iii). Similarly, a 2011 report by the WB points out that "youth unemployment rates in MENA (21 percent in the Middle East and 25 percent in North Africa) are higher than in any other region in the world. Young women and new educated entrants in the labor market are disproportionately unemployed" (Jaramillo \& Melonio, 2011, p. 3).

International development organizations suggest that these high rates of unemployment are the result of a "mismatch" between the real needs of the labour market and the outputs of the education system, largely due to misaligned incentives. In its 2008 flagship report on education in the Middle East and North Africa, The Road Not Traveled, the WB criticizes the fact that demand for higher education is inflated by employment guarantees in the public sector, while demand for technical education is too low, stating: "The combination of free education at the secondary and higher levels and a policy of guaranteed employment in the public sector has had negative side effects: a demand for higher education that does not correspond to real economic needs" (World Bank, 2008b, p. 14). Michael Rutkowski, sector director for human development in the WB's Middle East and North Africa region, explained that "there are no proper signals sent to higher education establishments in terms of which skills are in demand, and which skills are not in demand," and, as a result, "what we see in the region is that those who graduate from universities cannot find jobs" (World Bank, 2008a). In response, development experts suggest that governments align majors with what is in demand by the economy, and they call for data on employment figures by college major in order to inform students and parents better (Wilkens \& Masri, 2011), an irony given that many students have little choice over what they study.

The technical literature summarized here paints a linear if simplistic equation between low quality and misaligned incentives in higher education, and high rates of unemployment and stagnant economic 
growth in the labour market. This equation is rooted in human capital theory, which views the primary purpose of higher education as skill development for the labour market. Human capital theory assumes that formal education enhances young people's skills, thereby making them more productive workers, and ultimately leads to higher wages and economic growth. The logic is clear: employment is the ultimate outcome of the higher education system, and, as such, high rates of unemployment are a sign of a failing education system - and one in need of reform.

\section{Quality Assurance as Solution}

Given the all-consuming crisis rhetoric, governments and higher education institutions across the region have identified the improvement of quality as a policy priority. There is never an easy solution to such systemic "problems," however. Waterbury (2020) has called this a "trilemma," whereby the public policy options available to leaders involve a trade-off between quantity, quality, and costs. It is worth noting that a significant increase in government spending on higher education is rarely mentioned as a reasonable policy option. Instead, the most common approach to improving quality across the region has been the creation of new regulatory bodies - quality assurance agencies - that promise external accountability and oversight. Implicit in this "solution" to the problem of low quality is the assumption that universities, administrators, and faculty members cannot be trusted to maintain a high level of quality on their own. Rather, accountability for improving quality is shifted to independent agencies and councils.

The efforts to improve quality through accountability-enhancing initiatives are supported by the major players in global development. In 2007 the Arab Network for Quality Assurance in Higher Education (ANQAHE) was founded as an independent, non-profit organization to improve the capacity for quality assurance in higher education throughout the region. The network is supported by the Global Initiative for Quality Assurance Capacity and funded by the WB and UNESCO. In a study conducted in 2012 the ANQAHE found that twelve countries in the region had independent quality assurance agencies, while another ten, including Lebanon, Tunisia, Syria, and Qatar, did not have independent agencies. In these countries quality assurance tended to be vested in various departments of the Ministry of Higher Education or its equivalent. Nonetheless, the ANQAHE equates the absence of an independent agency with a lack of seriousness about quality. The report stated that the fact that almost half of the countries in the region did not 
have an independent quality assurance agency was a "rough indication of the reluctance of some countries to tackle the endemic problem of higher education quality" (ANQAHE, 2012, p. 22). In fact, studies have argued that Lebanon, Tunisia, and Qatar have among the best higher education systems in the region (el-Araby, 2011), suggesting that the link between "high quality" and "quality assurance" is not so simple.

\section{The Role of the World Bank}

In the context of the quality crisis, Arab governments have often initiated large-scale reforms to their higher education systems. Educational reform is typically understood as a deliberate, planned effort to improve education and is most often initiated to correct perceived broader social problems (Tyack \& Cuban, 1995). Though framed as a singular and time-bound event, "reform" has actually become so pervasive that many argue that it has become the norm in most educational systems. A key insight from decades of global educational reform is that defining and labelling social ills, often resorting to the rhetoric of national crisis, helps to grease the wheels of reform (Sahlberg, 2016). In examining the rhetoric around higher education reform in Morocco and Egypt, Kohstall (2012) finds a similar process in the Arab world. He argues that the all-consuming crisis rhetoric has been used to justify reform, typically in the direction of neoliberal policies, such as raising tuition or expanding privatization. He contends that "the production of a narrative on the crisis of higher education could be considered as the precondition for its reform. In reality, it is an ongoing process that is recycled each time when crucial reform steps are undertaken" (p. 100).

A common approach adopted by middle-income countries has been the convening of higher education leaders and politicians for national conversations about quality enhancement, with the goal of generating a "national consensus" about higher education reform. In 1998, Egypt's higher education minister set up a National Committee for the Enhancement of University and Higher Education. In a similar drive for reform, Morocco's King Hassan II launched the Special Commission for Education and Training in 1999 to debate reform options. The commission was carefully crafted to forge a political consensus, with every political party that was represented in parliament sending at least one member to the commission. Through this process, a national educational reform agenda was developed in 1999, called the National Charter for Education and Training (Charte nationale d'éducation et de formation), and key components of the charter were developed into legislation and passed into law by the Moroccan parliament in 2000. 
That said, Kohstall (2012) explains that despite the seeming consensus around reform, it was not clear how reforms would be translated into policy. Moreover, despite the seeming will for reform, in practice the implementation stalled.

I was living in Morocco when King Mohammed VI made an impassioned speech on public education to the nation on 20 August 2013, the sixtieth anniversary of Morocco's "Revolution of the King and the People," in which the French protectorate's authorities deposed the then sultan, Mohammed V, an act that is viewed today as having ultimately strengthening the nationalist independence movement. The king skilfully compared the country's revolution against colonization to today's revolution for human development and social and economic progress. He pointed out that he himself was a graduate of the public-school system and the Law School of Mohammed V University in Rabat, and yet he stated in no uncertain terms that he was "indeed sad to note that the state of education is worse now than it was twenty years ago." He also used the platform as an opportunity to blame the prime minister and the opposition party for their failure to enact reforms ("Full speech," 2013).

When government-initiated reforms stalled in Egypt and Morocco, development agencies played a critical role in helping governments secure the political will to enact reform. Kohstall (2012) explains that "in both cases international development agencies had a crucial impact" (p. 97). There is no reason to think that Arab governments uniformly resisted; in fact, development agencies promised additional resources that could facilitate the passage of desired reform. By aligning reform models to external best practices and expertise, Arab governments were also able to signal their seriousness about reform to sceptical publics.

As a result, quality assurance reforms are typically accompanied by funding and technical expertise from the WB. Large-scale reform in the name of improving quality has occurred in many of the middle-income countries in the region, including Egypt, Jordan, Morocco, and Tunisia. In North Africa, quality assurance for the knowledge economy has occurred in parallel with the restructuring of higher education to mirror the European reforms known as the Bologna Process. The outsized role of development agencies, however, also means that approaches to quality have been dominated by technical approaches and human capital theory. Suggested reforms followed generic models of quality assurance in international development, including the formation of an independent agency to oversee quality assurance processes and the systematic review of educational programs to meet minimum standards. In this model, quality assurance is treated as a primarily technical issue rather than one of resources or politics. In fact, the technical 
understanding of quality seems to dominate discourses of reform, even when it is accompanied by significant changes in university governance, including reform that transfers power away from institutions or administrators to independent agencies.

Since the late 1990s the WB has funded numerous higher education reform projects that are focused on improving quality throughout the middle-income countries in the region, often resulting in the creation of new quality assurance agencies accompanied by a host of other reforms. Table 3.1 shows the varied higher education projects funded by the WB over the past two decades.

In 1996 Jordan's Council for Higher Education was established to oversee quality assurance and accreditation. At the time, however, the council's work was limited to the accreditation of private universities; it did not regulate quality or have jurisdiction over public universities (Sabri, 2011). In 2000 the WB funded the Jordan Higher Education Development project for roughly USD 35 million, and a subsequent project, Higher Education Reform for the Knowledge Economy, for USD 25 million in 2009. Combined, these projects created new structures to manage levels of quality in higher education. In 2007 Jordan established an independent Higher Education Accreditation Commission, which for the first time set the same guidelines, criteria, and accreditation for both public and private universities. Subsequently, in 2012, the government passed a higher education law that defined clear standards of quality, such as maximum student-faculty ratios, campus size, and resources.

Egypt's reforms were also supported by the WB. The process began with the adoption of a WB credit line and committed to a series of six projects, monitored by a project management unit that included not only Egyptians but also representatives of international donors (Kohstall, 2012). The first of these projects, the Higher Education Enhancement Project, was launched in 2002 with USD \$50 million and established the Higher Education Enhancement Project Fund to provide small grants to university faculties so that they could design new programs or reorganize university administration. These grants, while popular with some primarily young and foreign-educated faculty members, benefited science and technical faculties more than the arts and sciences. Moreover, they were "a drop in the ocean" and left the faculties of Commerce, Law, and Literature "largely untouched," despite the fact that they enrolled upwards of 70 per cent of students (Kohstall, 2012, p. 104).

The second WB project was significantly more controversial: it involved establishing the NAQAAE as an independent governmental body to oversee and regulate universities. The proposed law sought 
Table 3.1. World Bank Projects in Higher Education

\begin{tabular}{lclc}
\hline Country & Year & Project title & USD millions \\
\hline Egypt & 1989 & Engineering and Technical Education Project & 31 \\
& 2002 & Higher Education Enhancement Project & 50 \\
Jordan & 2000 & Jordan Higher Education Development & 35 \\
& 2009 & Higher Education Reform for the Knowledge Economy & 25 \\
Lebanon & 1998 & Vocational and Technical Education Project & 63 \\
Morocco & 2010 & First Education Development Policy Loan & 60 \\
& 2012 & First Skills and Employment Development Policy Loan & 100 \\
& 2013 & Second Education Development Policy Loan & 100 \\
& 2014 & Second Skills and Employment Development Policy & 100 \\
& & Loan & 95 \\
Tunisia & 1989 & Education and Training Sector Loan & 75 \\
& 1992 & Higher Education Restructuring Project & 80 \\
& 1998 & Higher Education Reform Support & 99 \\
& 2000 & Education Quality Improvement Program & 76 \\
& 2006 & Second Higher Education Reform Support & 70 \\
\hline & 2016 & Tunisia Tertiary Education for Employability Project & \\
\hline
\end{tabular}

Source: World Bank (2021)

to externalize authority away from self-governance, while also ignoring the financial and structural inequalities between institutions that explained the differences in quality. The new law stoked the 9th of March, a movement of professors and academics working to defend the autonomy of the university (Farag, 2010; Kohstall, 2012). The 9th of March movement presented an alternative draft law on accreditation that called for wider participation. Eventually the NAQAAE was established by a presidential decree in 2007 and now operates as an independent body that reports directly to the Egyptian president, prime minister, and parliament. Kohstall (2012) argues that the intense political battles over the establishment of the NAQAAE were in part because the reforms were initiated from the outside, largely disregarding the autonomy of the university, and in part because it would disrupt the status quo; Kohstall stated that much of the resistance came from "those defending their privileges" in the current system (p. 105).

The case of Lebanon stands out as an instructive outlier. In Lebanon, quality assurance has proved to be highly political, with politicians 
being unwilling to commit to a fully independent regulatory body. For almost a decade, experts have been calling for an independent national higher-education quality-assurance body (Hasrouny, 2011). A law was drafted in 2012 to create an autonomous national quality assurance agency for Higher Education. Lebanese higher education experts, including professors and the Lebanese Association for Educational Studies, played a large role in drafting the law and insisted on the full independence of the agency. Politicians at the highest levels of government, however, wanted the agency to be housed within the ministry itself, which reform experts predicted would undermine the legitimacy and independence of the agency. For years the law has remained unsigned, however, exemplifying the stagnation that occurs when the government does not have the political will to enact change.

In April 2019 Lebanon introduced a draft reform that would cut public-sector salaries, including those of professors at LU, the country's largest and only public university. The proposed reforms are part of the government's attempt to secure a loan of USD 11 billion from the IMF for broader economic reforms focused on infrastructure and economic growth; however, they entail significant cuts to public spending. On 6 May 2019, professors at LU began a general strike and protests at Parliament to resist further cuts to the university. As the most affordable institution, the LU plays an important role in the country. Unlike private institutions where tuition is upward of USD 7,000 a year, the LU charges registration fees of USD 500 for Lebanese nationals and USD 1,000 for non-Lebanese, including Syrian refugees. Professors argue that strikes are necessary to protect the quality of higher education in Lebanon. Systematic funding cuts have reduced the university budget to USD 250 million. There is a great irony in the fact that the IMF, sister agency to the $\mathrm{WB}$, is encouraging across-the-board cuts to public-sector institutions, while the WB and other development agencies continue to support investments in higher education for a knowledge economy.

\section{Europeanization in North Africa}

The WB played an influential role in supporting quality assurance in North Africa when countries throughout the region decided to undertake major structural reforms to align their higher education systems with those in Europe. In 1999, countries in Europe committed to aligning and harmonizing their higher education credentials to allow for intra-Europe mobility in both education and employment. In France this entailed changing its credentials to a three-year licence (bachelor's degree), a two-year master's degree, and three-year doctorate, known as 
the licence-master-doctorat (LMD) system. In addition, the new degrees are based on the model of credits, with a bachelor's degree requiring 180 credits and a master's degree awarded after another 120 credits. Shortly thereafter, countries throughout North Africa made political commitments to restructure their higher education systems similarly in order to harmonize degrees as part of a broader Euro-Mediterranean higher education area. These reforms institutionalized a new structure of a threeyear bachelor's degree and were coupled with other curricular changes, including the introduction of professionally oriented master's degrees and continuous assessment. The shift from a four-year bachelor's degree to a three-year bachelor's degree was a significant change, as it reduced the time required to complete a degree, but it also removed what many saw as a critical fourth year of learning for undergraduate students.

In Tunisia a major higher education reform to align to the Bologna Process began in 2005 and constituted one of the largest reforms since the county's independence. In 2006 the Tunisian government initiated a higher education reform called the Programme de Developpement de l'Enseignement Supérieur et d'Appui à la Qualité (Higher Education and Quality Support Development Program), which was framed as supporting the country's knowledge economy aspirations by improving graduates' learning outcomes. It had an added benefit of aligning Tunisian credentials to the LMD system used in Europe. A new law gave all universities the opportunity to restructure their degree programs in line with the LMD system within three years, and all had done so by 2006 (World Bank, 2015).

The idea of quality assurance, a core component of Europe's LMD reforms, was also introduced and supported by international donors including the WB and the European Union. Between 2006 and 2014 the WB provided a loan of USD 76 million to support Tunisia's reforms through a project called the Second Higher Education Reform Support Project, which followed two prior loans made in the 1990s (World Bank, 2015). The WB project funded the construction of four new higher education institutions, created a funding mechanism known as the Quality Promotion Fund to provide competitive block grants to universities, and, importantly, created a comprehensive quality assurance system for the higher education system. Specifically, WB investments were targeted to "develop a quality assurance and accreditation system" and to "develop financing mechanisms that provide higher education institutions with incentives to improve their quality and performance" (World Bank, 2015, p. 2).

Prior to this, oversight for quality in Tunisia had been managed by the Comité National d'Evaluation (National Committee for Evaluation), 
which was created in 1995 to carry out internal evaluations of Tunisian higher education institutions. In 2008 a new law was adopted to refine concepts and practices associated with quality, including the creation of a national body for evaluation, quality assurance, and accreditation. The law established an independent quality assurance agency, known as the National Institution for Evaluation, Quality Assurance and Accreditation (IEAQA), that would be responsible for external review and accreditation of both public- and private-sector universities. In practice, implementation was slow. It was not until a 2012 decree that the agency was effectively established, and not until 2015 that it began actual evaluations of Tunisian universities.

The WB has continued to support Tunisia in its higher education reforms. In 2016 it approved an additional USD 70 million for higher education. The press release announcing the new funding stated that the project sought to "address the high levels of unemployment among university graduates in Tunisia" through "ongoing reforms to improve the management of universities and the quality of teaching, and to ensure that students are graduating with the skills demanded by the labor market" (World Bank, 2016).

The case of Morocco has followed a similar path, mirroring Tunisia in both its fast adoption of the LMD system and its slow implementation of independent quality assurance. In Morocco, major higher education reform had been on the agenda since the mid-1990s with the creation of the Special Commission for Education and Training, discussed earlier, and was identified as a key priority under the late King Hassan II. The principle of quality assurance was included as part of the major reform package passed in 2000. Specifically, the Higher Education Organization Act (Law 01-00) required that courses in public and private institutions be accredited and evaluated. In addition, it stated that an official body must be created to assess and regulate the higher education system. Two new national bodies were established: the National Coordination Committee for Higher Education and the Coordinating Committee for Private Higher Education, which were founded in 2003 and 2005, respectively, to license new public and private universities. As part of the same reforms, a fifteen-member National Accreditation and Evaluation Committee was also created to accredit programs, including all new master's degree and doctoral programs. That said, unlike the independent quality assurance agencies that represent best practice supported by development agencies, the three committees were essentially consultative and composed of members who were, for the most part, appointed academics. Their responsibilities were limited largely to delivering opinions on policy matters. 
In contrast, the LMD reforms were not officially part of the 2000 reforms. Benchenna (2009) explains that neither the national charter, carefully constructed to appear to be a national political consensus, nor the actual law passed in 2000 includes a "single explicit mention of the LMD architecture" (p. 124). Instead, the LMD system came from outside the country and was adopted even before it was legally decreed. In 2002, at a meeting of France's Council of University Presidents and Morocco's university presidents, the French advocated for the LMD system, and by January 2003, Moroccan university presidents had adopted it during a national educational conference. Less than a year later, in the 2003-4 academic year, universities began introducing the first bachelor's degree programs under the new system. Among Moroccan university stakeholders, the reform was viewed as imposed on them. In their research with Moroccan academics, Ergül, Coşar, and Mous (2017) quote a professor who explained that the government "brought the reform, put it on the table and said 'take it or leave it'" (p. 162).

It was not until June 2004, however, that the government issued a decree making the LMD system official. Kohstall (2012) stated that Europe's "international model acted like a 'magic wand' for a reform that remained for a long time under debate" (p. 105). While the reforms were justified in the name of improving the quality of learning and the employability of graduates, in reality the reforms were primarily the result of French influence in North Africa (Benchenna, 2009). Kohstall (2012) explained that, "with the LMD reform on the way in Europe, France reactivated its old role as an exporter of ideas and cultural policies towards the Maghreb and francophone Africa" (p. 106).

By 2008, the government was convinced that the broader 2000 reforms had stalled. They initiated the Education Emergency Program (Plan d'Urgence) to help meet the goals of the 2000 charter, which was supported by two large WB loans, in the amounts of USD 60 million for the first Education Development Policy Loan in 2010 and an additional USD 100 million for a second Education Development Policy Loan in 2013. While both focused primarily on improving access to lower secondary schools, two additional loans, the Skills and Employment Development Policy Loans of 2012 and 2014, both directed funding to higher education to address the issue of employability. Much of the funding focused on expanding access to vocational training, and university funding was tied to performance on key indicators (Jaramillo \& Melonio, 2011; Waterbury, 2020).

Building on the 2009-12 reforms, the Ministry of Higher Education initiated an action plan for 2013-16 including a number of projects focused on higher education. This action plan specifically included "the 
development of a quality assurance system" as a key objective and also called for the implementation of other projects such as the construction of new higher education institutions. The WB specifically supported the creation of an independent quality assurance agency, and a decree was issued in 2014 to formally establish the National Agency for Assessment and Quality Assurance in Higher Education and Scientific Research (ANEAQ). The ANEAQ was founded as part of a pan-African project funded by the European Union, called the Harmonisation of African Higher Education, Quality Assurance and Accreditation (HAQAA) and supported by both the European Union and the African Union.

Across the region the shift from internal to external accountability through the creation of semi-independent quality assurance agencies is clear. Similarly, Kohstall (2012) argues that "'quality assurance' has become the central reference for reform" (p. 95) and that this has been accomplished primarily through the "transfer of international models" (p. 96). There is a clear reliance on external actors and ideas; WB loans have been used to support the adoption of a European degree system. Meanwhile, WB funding has brought about the creation of particular independent agencies, and European Union funding has trained academics in quality assurance. These external influences have played an important role in securing the legitimacy and funding needed to take on large-scale quality-enhancing reforms.

In North Africa, where national governments more or less copied European reforms wholesale with little national debate, the reform process largely sidelined the local policy processes. Members of the local policy community felt that these reforms were imposed from the outside, with little substantive debate by legislators or Parliament (Ghouati, 2009). Academics, rather than being agents of change, were treated as "the passive executors of already-set policy agendas" (Ergül, Coşar, \& Mous, 2017, p. 164). The process epitomizes the neocolonial experience: six decades after independence, educational policies in Morocco and Tunisia are still dictated by reforms in France.

A greater irony is that many academics with whom I spoke in Morocco argued that the LMD reforms were actually bad for student learning: they shortened the time to completion of a degree by a full year and, in so doing, watered down the educational content provided by a degree. Reforms made in the name of improving quality resulted in students graduating with a bachelor's degree and entering the labour market with less time to master concepts and develop their skills. Throughout my many years of living in Morocco, one of the constant refrains I heard from academics in the decade after adoption of the LMD reforms was that they had been a disaster for the higher education system - largely 
because the adoption was associated with students learning less, not more. Interestingly, in January 2020, the Moroccan minister of higher education announced unexpectedly that the ministry was reverting course and would be adopting a four-year bachelor's degree in line with the American model (Sawahel, 2020). In making this announcement, he cited ideas of efficiency and quality, stating that the shift would "allow Morocco to open up to international education systems, especially those in Anglophone countries that have demonstrated their efficiency and quality" (Sawahel, 2020).

\section{Relying on External Advice in the Arab Gulf}

Rather than relying on WB projects to secure external funding, Qatar and the UAE have taken a different approach: they have brought in external consultants to align their higher education systems to global best practices. Nonetheless, their reforms to improve quality are similar to those in other countries, centred on enhancing "rigour" through independent commissions and on raising admissions standards.

In the early 2000s the UAE established the Commission for Academic Accreditation (CAA) as a fully independent body that licenses the country's many public and private universities and accredits each of their academic programs. The CAA aims to ensure that programs in the UAE meet international standards of accreditation. Its mandate includes licensing private universities, accrediting programs, and supporting institutions in their development of quality assurance mechanisms. As a high-income nation, the UAE is not influenced by the possibility of WB funding but nonetheless relies extensively on foreign consultants, and it has a history of importing the best practices articulated in international higher education development discourses (Ridge, 2014).

More than nearly any other country, Qatar put its faith in external and technical experts to reform its educational system (including Qatar University). In 2001, Qatar's Supreme Education Council commissioned an international think-tank, the RAND Corporation, based in Santa Monica, California, to advise and oversee major reforms to the country's educational system. RAND's advice largely reflected American models of education policy, and in response to Qatar's primary- and secondary-school system underwent reform, including the introduction of independent schools, the publication of school report cards, and the switching of the language of instruction in science courses to English. Although some reforms were welcomed, over the past fifteen years the reforms have become widely criticized on various fronts, with debates ranging from whether the reforms were simply not 
in place long enough to be effective, to whether Qatar was losing its culture by teaching in English. Others have criticized the reforms as fundamentally ineffective, because Qatar remains low performing on internationally comparative assessments.

In higher education, starting in 2003, the Supreme Education Council also engaged RAND to help with major reforms to Qatar University as part of the same drive to reform education for a knowledge economy. The partnership was initiated by Qatari leadership in response to perceptions of declining quality, including the areas of time to graduation and student engagement, and RAND's formal role was one of supporting university-initiated reforms. As part of its reforms, Qatar University created the Senior Reform Council, composed of senior administrators, professors, and experts from universities in the United States and the United Kingdom. At the university level, reforms focused on the enhancement of administrative operations by improving institutional autonomy and decision-making processes, as well as revitalizing academic offerings, improving faculty quality and performance, improving student achievement, and strengthening the university's sense of community.

One of the strategic decisions made at the time was to uphold high academic standards in the name of quality. In their monograph The Reform of Qatar University, Moini, Bikson, Neu, and DeSisto (2009) explain: "Faced with preserving the status quo, in which a university education was available to all nationals, or upholding academic standards, the administration decided that QU would uphold its new standards and aim to serve average and above-average students, while expanding its preparatory Foundation Program" (p. xxiv). One of the overarching goals was to "foster and support student achievement," and, under this objective, key recommendations included strengthening and standardizing admissions requirements, setting minimum standards for retention, and codifying academic regulations. What is striking about these recommendations is that they focus entirely on student preparation and performance, while hardly addressing university-based supports for learning. The reality is that while upholding high academic standards sounds like a perfectly legitimate policy, in practice it means excluding students with weak secondary-school records.

In an interview that I conducted in Qatar in 2019, one researcher described how external reforms were implemented with little local buy-in and created significant resistance: "They revamped Qatar University between 2003 and 2006, and the plan was in place to transform the institution, but there was resistance and complaints. The country's leadership realized that they [the reforms] had disrupted society too much. It was too much for society to absorb, and the main audience for 
reform is the citizens." He continued: "Although some aspects of QU have become more modern, and students are better than they were in 2002, the plan was to move it to be state of the art overnight"; on that front, he said that "the reforms did not accomplish their goals."

Although it is clear that countries throughout the region have taken different routes, the profiles of reform provided here suggest that governments have turned to the international arena - including the WB, the European Union, and consulting firms based in the United States to secure the resources and political will needed to institute largescale reforms in the name of high quality. As a result, quality reforms are often viewed as being imposed from abroad with little local debate, contextualization, or localization. Criticisms are made in the Arab Gulf states of the extent to which the region is reliant on external expertise and global models that lead to reforms that are not desired by local constituencies. In 2013 the Qatar Foundation formally ended its contract with RAND, and the RAND-Qatar Policy Institute closed. A decade after Qatar University reforms were initiated, they are widely viewed as a model for what not to do: external consultants instituted rapid changes, and in their wake many Qataris felt there was no place for their children in higher education. In both the Maghreb and the Arabian Gulf, national populaces contest the idea that embracing the international has been successful in improving the national system. Donn and al-Manthri (2010) argue that the policy frameworks and much of the ministerial discourse adopted by the Gulf Cooperation Council (GCC) countries regarding higher education originate in the former group of eight industrialized nations and are promoted by a "magistry of influence," which relies heavily on foreign expertise (p. 141). They contend that the particular vision of high-quality higher education that circulates among foreign organizations and consultants "is not necessarily one developed in the broader MENA and may not even be appropriate for the region as a whole" (p. 151). It is not surprising then that nearly two decades of reform seem to have had little impact on discourses of declining quality and failing institutions.

\section{The Limits of Quality Assurance}

In 2016, I asked Dr. Adnan El Amine, a prominent scholar of Arab higher education and the director of the Lebanese Association for Educational Studies, whether any country in the region had done quality assurance well. He replied: "No, no. They believed, or they claimed, that these agencies would resolve the problem, but you may be sure, these agencies have not resolved the quality issue." Indeed, despite the flurry of 
reforms, quality assurance policies seem to have had a relatively minor impact on higher education systems in the region. Quality assurance reforms have tended to be additive, leaving broader structural and political constraints unaddressed.

For the most part, quality assurance reforms have typically resulted in the creation of new councils or agencies, which are often added onto and independent of the existing system. Reforms have established minimum standards for entry into private universities, regulated standards such as library facilities, and required individual institutions to undergo an internal quality review or external accreditation. However, they rarely address structural issues and constellations of interests that determine the status quo in higher education systems.

Quality assurance policies and practices seek to align to global best practices while not disrupting the interests of local audiences. As a result, quality assurance has become a platform upon which other political interests are contested, and it serves as a pretext for other reforms. The technical literature imagines and advocates the creation of independent and autonomous quality assurance agencies. And yet in almost no country in the Arab world is the quality assurance agency independent of other state authorities. There is nothing surprising about this lack of independence: Waterbury (2020) recounts long histories of government interference in the operations of Arab universities, including firing rectors, replacing deans, and firing academics, as well as installing secret police on campuses (p. 63). As a result, despite promises of independence, the composition of quality assurance agencies, their mandates, and their power to regulate universities are often politicized. In many cases university administrators and quality assurance commissioners are directly appointed by rulers, making them essentially political appointees rather than academic experts or professionals. One of my interviewees stated that this was yet another "boutique" for the state to play politics.

In Jordan, the director of the Quality Assurance Agency exerts significant control over all universities, akin to what one of my interviewees called "a super minister." One interviewee said that the director of the agency was close to the king and focused on "marginal aspects of quality just to say 'I am controlling you.' It is a formal authority over universities, rather than really improving quality." The concentration of power in a political office has meant that the king retains significant control over issues of university quality in Jordan. In practice, this means that the raising of admissions or graduation standards that would negatively affect loyal constituencies, and the reduction of numbers of university staff to improve efficiency in rural parts of the country where universities are major employers, are all unlikely reforms. 
In the UAE, the CAA was considered unique in the region because it was established as a fully independent body and given power to shut down poorly performing universities. Yet my interviewees suggested that the creation of the quality assurance agencies was one way in which the government could enhance employment of Emirati nationals, a policy priority for the country. In 2016 the UAE required all professors to undergo a certification of their university credentials and establish their equivalency in the Emirati system. This policy was framed as an attempt to ensure the integrity of academics' credentials. Many faculty members who had completed their doctorates abroad were highly critical of the policy and insisted that the degree-certification process was a waste of time. One professor, who had completed a doctorate in the United States, explained: "This is a way to create jobs. It is another government office. It is another way to tax the [foreigners] without officially creating a tax. Now we have another governmental department where Emiratis have to work, and it's also a way to tax people, because we [foreign faculty members] have to pay for the degree certification."

In the UAE, a country with a significant expatriate labour force, the role of foreign faculty members was a constant source of tension. In interviews that I conducted with professors in 2016 in the UAE, they said that the Emirati academic labour market, where professors worked on impermanent contracts, undermined the country's stated commitments to quality. One faculty member at a private university in the UAE explained that his university was in the process of seeking American accreditation, which was a time-intensive process; however, faculty members had very little reason to participate in the process: "You know, why would we even worry about this? Students will be here longer than we are. At any point the university administration can cancel your contract, and you are going to have to leave the country."

In middle-income countries one of the most important structural issues is student enrolments. Many universities are required to accept more students than they can accommodate; in other cases, students are funnelled into programs for which they have little interest. For example, despite the official commitment to apply the same quality standards to public and private universities in Jordan, administrators told me that public universities cannot actually meet these standards because they do not control their own admissions. In an interview I conducted with the former vice-president of a public university in Jordan in 2013, he explained that the university administration requests a certain number of students from the centralized Unified Higher Education Admissions Council, but "they don't respect that number. Usually you get double or triple that number. The university requested 3,000, and we ended up 
taking 8,600 incoming freshmen $-8,600$, when we think our capacity is stretched to the limit at 3,000." Similarly, one official at the Higher Education Accreditation Council, who oversaw quality assurance efforts and with whom I spoke, agreed that estimates of capacity were regularly exceeded: the council estimated public universities could absorb 22,000 new students in 2013, but over 40,000 students were placed at their institution by the central authorities. He explained that this constituted a real barrier to meeting quality standards. He stated, "If we wanted to meet international standards of student to faculty ratios, we would need to hire between 1,500 and 1,700 new faculty members."

In Egypt in 2016, I met a professor of English at a public university who explained how their program navigated the grey zone of language, admissions, and quality. As the centralized admissions system allowed students with very poor English to enrol in their program, they had been assigned two hundred incoming English majors, many of whom were neither interested nor proficient in English. In response, the faculty instituted an unofficial and department-specific languageproficiency test that required students to have an intermediate level of English to actually enrol, which cut enrolments in half. "Even though the required level was not high," she said, "the change to the department was remarkable. Professors had more time to devote to students who were enrolled, and were able to hold them to higher standards for reading and literary criticism." As a result, their graduates began to establish a reputation and were recruited to teach in many schools around the city. Despite the improvements in student learning, such a practice actually denied many students a place in the university, and faculty members were accused of favouritism or offered bribes to enrol students who did not qualify, exemplifying the structural realities that shape learning in the Arab world and which can hardly be solved by independent accreditation bodies.

A second important structural issue is employment. Universities are major employers throughout the world, and administrative positions in public universities represent a highly desirable employment for many middle-class families in the Arab world. This may be particularly true in the more rural and less industrialized parts of the region. Employment, like admission, serves as a convenient form of political patronage, which means that public universities tend to have more administrative staff members than are needed (Waterbury, 2020). Moawad al-Kholi, the former president of Menoufia University in Egypt, reflecting on his experience as president, is quoted by Elmeshad (2014): "I have enough staff in the university administration for 10 universities" - which obviously affects the university's budget. Similarly, Waterbury (2020) 
implies that the reason Mohammed V University in Rabat, Morocco, was divided into two campuses in 1993 was to create more senior-level administrative posts as a form of patronage to loyal constituencies. The result was an unnecessarily divided institution, which was eventually reunited in 2015.

In the absence of state assurances of high quality, many institutions are pursuing alternative and external markers of quality levels, particularly international accreditations that can stand as signifiers in the global era (Farag, 2010). Universities throughout the region already actively pursue these accreditations, including through the regional accreditation bodies of the United States and professional accreditations in business and engineering programs. While there are many benefits to these accreditations, they also imply that the Arab states' university credential does not stand on its own as a symbol of high quality and may continue to erode confidence in the public sector.

\section{Quality and the Linguistic Hierarchy}

Discussions of quality map onto long-standing language hierarchies. At the institutional level, programs with more restrictive admissions standards and lower acceptance rates tend to be those that teach in foreign languages. In particular, the sciences and business tend to be taught in French or English, while the humanities and social sciences are taught in Arabic. Throughout North Africa and Lebanon, in public universities, students in the humanities or social sciences, including law and literature, study in Arabic, while those in engineering and sciences study in French or English.

The rank ordering of degree programs in Arab societies, with medicine and engineering at the top and social sciences and humanities at the bottom, discussed in chapter 2 , also creates a vicious cycle that perpetuates assumptions of low quality in the social sciences and humanities. As they maintain lower admissions standards, they are often viewed as "catch-all" fields for students who have not been accepted into more prestigious or difficult programs. The social sciences and humanities tend to be taught in Arabic, not English or French, have large classes sizes, and have fewer resources, synonymous with low quality. Perceived as low quality and low prestige, these programs have a difficult time attracting more academically motivated students who might otherwise be interested in the social sciences and humanities. Government policies and social attitudes combine to perpetuate the idea that graduates of social sciences and humanities are less qualified (Cantini, 2012). Reflecting on the power of these discourses, Cantini (2012) cites 
Sami Khasawneh (2001) as stating that "there is an essential difference between the students of the humanities and those studying sciences," namely that "the scientific student is interested in learning and willing to promote change even at a societal level, while the humanistic student is less motivated and interested, since the only reason to pursue this career is to have failed the access to the scientific one" (Cantini, 2012, para. 27, citing Khasawneh, 2001).

This self-perpetuating cycle is realized in full when the graduates of low-prestige fields enter the labour market with credentials that some of my interviewees called "meaningless." Indeed, many young people understand the ways in which discourses of low-quality map onto various degrees. A Lebanese man I interviewed in Beirut in 2016 exclaimed: "If you study law at the Lebanese University, you are just giving up. If you study Arabic literature at the Lebanese University, you are also giving up, but at least you get to read interesting stories." This hierarchy of prestige is reinforced by families who encourage students to study subjects that are viewed as competitive and prestigious.

In fact, according to my interviewees, many of the most contentious debates over quality reform at Qatar University were actually debates over the role of Arabic as a language of instruction. English is the medium of instruction at the Education City campuses, and Arabic was used originally to teach the social sciences and humanities subjects at Qatar University. This linguistic division implied that Arabic was the language for the masses, while English was the language of the academic elite. When the 2003 reforms changed the language of instruction to English throughout Qatar University, there was the feeling that there was no place for some Qataris who would be better served by studying in Arabic. In 2012, five years after the RAND project had officially ended, the Supreme Education Council announced that the language of instruction in the social sciences would return to Arabic. Today, the colleges of education, arts, and humanities and of law and Islamic Studies all teach in Arabic, while the colleges of science, engineering, and business all teach in English.

The ranking of knowledge along linguistic and curricular lines has a dual effect: it simultaneously undermines the legitimacy of the Arabic language as a language of knowledge and science and frames the humanities and social sciences as less valuable. This linguistic hierarchy has also increased the demand for private primary and secondary schooling that teaches in foreign languages, and it has put particular pressures on low- and middle-income families to learn those languages. In North Africa, Boutieri (2012) carefully deconstructs how language abilities determine students' opportunities. The most prestigious 
degrees, engineering and medicine, are only available to those who are skilled in French. As a result, even middle- and lower-class families speak to their children in French or send their children to Frenchmedium private schools at young ages.

\section{Reconsidering Higher Education and the Labour Market}

In terms of the labour market, technical discourses that view the path from education to employment as linear are overly simplistic. In reality, the region's high rates of unemployment may have very little to do with what, or whether, students are learning in university. Labour markets in the region are characterized by substantial reliance on the public sector, as well as on many family-run businesses and a large informal sector (Assaad, 2014; Kabbani, 2009; Kabbani \& Kothari, 2005). They are also heavily segmented along lines of gender and nationality due to policies and social norms, all of which contribute to high rates of unemployment particularly among young people and women (Barsoum, 2016; Kabbani, 2009; Mryyan, 2014; Salahi-Isfahani \& Dhillon, 2008. The preference for public-sector employment is common across the region but is particularly acute in the Arab Gulf states, where, with relatively low levels of education, national citizens can obtain well-paying and comfortable positions. Most Arab Gulf states have initiated labour-market-nationalization policies, which require private companies to hire a certain proportion of nationals (Forstenlechner, 2008). Many of the professors with whom I spoke in the UAE felt that these policies likely decreased students' motivations for studying by weakening the link between education and employment.

Moreover, personal or family connections, known as wasta in Arabic, are powerful means to finding employment. Scholars have noted that in the Arab world "personal, kinship, and social networks play a particularly important role in accessing employment" (Krafft \& Assaad, 2016, p.3). Wasta, however, does not necessarily imply corruption or perverse forms of nepotism; it also represents what sociologists have called "the strength of weak ties" because many young people use personal, kinship, or other social networks to find employment (Granovetter, 1973). When I was living in Lebanon in 2016 and asked about labour market transitions, one young Lebanese woman replied: "Of course there are always those who just study some subject and they know they aren't going to work in it - they are going to get a job through wasta or with their family's company. I have a friend who studied at university, but she won't use the degree because her family owns a business. She says, 
'I want to study something easy because I already know where I will work.'" From an economic perspective, reliance on family networks undermines the university's human capital production. Assaad, Krafft, and Salehi-Isfahani (2018) examine a range of labour market outcomes for commerce and information technology graduates in Jordan and Egypt and find that family backgrounds matter more than educational factors. In their words, "family background variables drive labour market outcomes" (p. 970). They argue that "students and their families have little reason to seek out the type of higher education that builds productive skills, and HEIs [higher education institutions] ... have little reason to produce them" (pp. 970-1).

That said, it is not clear that the blame should be placed squarely on young people or their universities. In writing about young people's transition to the labour market in the Arab world, Momani (2015) argues: "Although there is no shortage of young, educated Arabs, many remain unemployed or underemployed after graduation, and face many challenges when seeking opportunities to take advantage of their education. These challenges include a corrupt political and social system rife with nepotism and family networks that stunt the ability of talented youth to compete on the basis of meritocracy" (p. 11). This labour-market-centric perspective contrasts starkly with the overwhelming consensus among policy advisers that the problem is primarily the poor quality of the education. In fact, the field would do well to consider what it means for policy that the weak link between education and employment may have more to do with the labour market than the university. Higher education administrators and ministries of higher education are not solely responsible for the current "crisis" of high unemployment, nor can they alone be expected to solve it.

\section{Reconsidering the Credential}

Reconceptualizing quality requires moving beyond the current emphasis on rigour. From a technical perspective, the goal of quality assurance is to ensure that students are learning. However, this narrow definition of quality misses the fact that the educational credential - not the knowledge or the skills it purportedly represents - is what most students and families desire above all. While economists view education as related to human capital, sociologists tend to view degrees as a positional good, the value of which is determined by their rarity (Collins, 1979). Meyer, Ramirez, Frank, and Schofer (2007) put it bluntly: "In the modern world, it does one little good to possess the skills of a university graduate if one lacks proper certification from a 
properly accredited university. Conversely, if an individual does carry the right documentation, his or her actual abilities are often treated as secondary matters" (p. 190). Similarly, when access to employment and economic stability are part of a broad social contract between the state and its citizens, reforms that curtail access to credentials by raising admissions or graduation standards end up denying many citizens what they perceive to be their rights or entitlements. These reforms are understandably contested, regardless of what may be their positive impact on indicators of quality.

In an older era of higher education, when universities were primarily elite serving, the legitimacy of the educational credential was guaranteed by its exclusivity. This model is still held up as a golden age by some - professors in Morocco have told me of their golden days studying for their doctorate in France, where they had close and personal interactions with famous scholars and theorists. In that era the university credential implicitly embodied a deep socialization process and envisaged its holders to be political and social elites. The rapid growth in university enrolments in Arab countries and around the world has democratized this formerly elite institution. In so doing, however, it has also weakened the relative power of the credential (Collins, 1979). The university credential is no longer a mechanism for signalling elite status; instead, it must now signal content mastery and transferable skills.

In the neoliberal era there is concern that the purpose of higher education has been further narrowed to the acquisition of the credential, not to the skills and knowledge it supposedly represents. In an interview I conducted in July 2016, a professor at a public university in the UAE explained that the major problem with her students was a lack of investment in learning: "A lot of our students don't perceive that the steps for getting the degree and the knowledge that you acquire [are] important. They just want to have the paper. If they could buy it, they would buy it." She attributed this to larger labour-market policies, which reward students who have more education with higher salaries. Tying financial incentives to degrees creates perverse incentives for students: "It increased plagiarism. We have a real problem with students buying papers." It is also common to hear of professors being pressured to give higher grades: "The bullying was insurmountable. I mean, they are nice people; they are not bullies. But we would have students in our face, harassing us, screaming, because it's money. It's financial for them." It is hard to see the impact of quality-enhancing reforms when students and families are willing to pay thousands of dollars to purchase an educational credential illegally. Maintaining 
high quality through close faculty-student relationships is time intensive and difficult; lowering standards is easier for everyone involved. A good level of educational quality benefits society as a whole, and yet the costs of quality assurance are borne by individuals and institutions who have many incentives for accepting less time-intensive forms of learning. Governments, administrators, and entrepreneurs all face pressures to lower admissions standards and accept more students for increased tuition fees. There are often real political incentives for doing so: Waterbury (2020) reminds us that, particularly in authoritarian regimes, higher education systems must "reinforce the legitimacy of the regime and shore up authority of the national leadership" (p. 158). This often entails expanding access to particular constituencies or appointing leaders from among allies, as forms of patronage. They also face pressure to reduce costs, by increasing class sizes or hiring professors on short-term contracts.

The human capital lens, which dominates the literature on higher education, assumes that education plays an important role in preparing young people for employment. In reality, young people attend university for a wide variety of reasons, including prestige, marriage, and personal independence. In fact, the sociological literature reminds us that for many young people university attendance is not primarily an economic calculation but rather is part of an individual's pursuit of status. Young people certainly want a high-quality education, but not if it excludes them. Prior research in the region has found that Egypt's upper-middle-class women view higher education as an intrinsic part of acquiring and maintaining a middle-class identity that involves no real calculation of outcomes (Sieverding, 2009). Different groups view education as a means to attain higher social status and, hence, pursue education out of a desire to avoid shame, maintain privilege, or advance their status group's economic or political interests. Higher education is also viewed as a place to find a future partner for marriage and childbearing. Some have argued that attending higher education benefits women in the "marriage market," which helps to account for females' strong demand for higher education but their low, and declining, labour-force-participation rates (Elbadawy, 2009). In my own experience with young people on university campuses in the region, I also found that, as in North America and Europe, universities are social spaces and present opportunities for students to interact with friends, to flirt, or simply to get out of the house and away from the watchful eyes of parents. In short, young people have multiple motivations for attending higher education that may have very little to do with eventual aspirations for employment. 


\section{Redefining Excellence as Both Political and Personal}

This chapter argues that it is time to rethink the concept of quality in higher education development. One avenue to redefining quality might start with moving away from focusing on institutional practices or student-level outcomes to reconceptualizing "excellence" as embedded within relations of care. Technical discussions of quality rarely focus on what occurs within the classroom and largely ignore the fact that teaching and learning are relational processes: students do not simply memorize knowledge in isolation; they are engaged in discussion and debates with scholars that serve as a form of mentoring and socialization. A relational approach to quality could focus on how students are learning, or pay particular attention to the role that universities are playing in socializing citizens for social and political outcomes. Current approaches to quality ignore the fact that faculty members are political actors, and many are on the front lines of strikes that are demanding better working conditions. This is often considered a detriment to student learning, rather than socialization into political participation. Similarly, an alternative approach to improving quality in the region could begin by recognizing the relational aspect of teaching and learning, focusing on how learning is occurring in community, and recognizing the "everyday excellence" that already exists throughout the region. One of the great casualties of the crisis rhetoric is that there is little incentive or interest in recognizing the intelligence, creativity, and impact of Arab professors and students. 